\title{
Antiviral Activity against Avian Leucosis Virus Subgroup J of Degraded Polysaccharides from Ulva pertusa
}

\author{
Yuhao Sun, ${ }^{1,2,3,4}$ Xiaolin Chen $\mathbb{D}^{1},{ }^{1,2,4}$ Lin Song, ${ }^{5}$ Song Liu $\mathbb{D}^{1,2,4}$ Huahua Yu, ${ }^{1,2,4}$ \\ Xueqin Wang, ${ }^{1,2,4}$ Yukun Qin $\mathbb{D}^{1,},{ }^{1,2,4}$ and Pengcheng $\mathrm{Li}(\mathbb{D})^{1,2,4}$ \\ ${ }^{1}$ Key Laboratory of Experimental Marine Biology, Institute of Oceanology, Chinese Academy of Sciences, Qingdao 266071, China \\ ${ }^{2}$ Laboratory for Marine Drugs and Bioproducts of Qingdao National Laboratory for Marine Science and Technology, \\ Qingdao 266071, China \\ ${ }^{3}$ University of Chinese Academy of Sciences, Beijing 100049, China \\ ${ }^{4}$ Center for Ocean Mega-Science, Chinese Academy of Sciences, Qingdao 266071, China \\ ${ }^{5}$ Qingdao University of Science and Technology, College of Marine Science and Biological Engineering, Qingdao 266042, China
}

Correspondence should be addressed to Xiaolin Chen; chenxl@qdio.ac.cn and Pengcheng Li; pcli@qdio.ac.cn

Received 6 February 2018; Accepted 17 July 2018; Published 5 August 2018

Academic Editor: Heather Simpson

Copyright (C) 2018 Yuhao Sun et al. This is an open access article distributed under the Creative Commons Attribution License, which permits unrestricted use, distribution, and reproduction in any medium, provided the original work is properly cited.

\begin{abstract}
Avian Leukosis Virus Subgroup J (ALV-J), a retrovirus of avian, has caused enormous economics losses to poultry industry around the world. Polysaccharides from marine algae are featured diversity bioactivities. To find the potential effect to prevent ALV-J spread, in this study, polysaccharides from Ulva pertusa (UPPs) and four low molecular weight (Mw) U. pertusa polysaccharides (LUPPs) were prepared and their functions on ALV-J were investigated. Firstly, LUPPs were obtained by hydrogen peroxide $\left(\mathrm{H}_{2} \mathrm{O}_{2}\right)$ oxidative degradation. The effects of degradation conditions on Mw of the UPP were also investigated. Results showed that the $\mathrm{H}_{2} \mathrm{O}_{2}$ oxidative degradation method could degrade UPP effectively, and the degradation was positively related to $\mathrm{H}_{2} \mathrm{O}_{2}$ concentration and temperature and negatively to $\mathrm{pH}$. The chemical characteristics of UPP and LUPPs were also determined. Afterwards, the anti-ALVJ activity of the polysaccharides were carried out in vitro. Results showed that UPP and LUPPs could inhibit ALV-J and LUPP-3 and Mw of $4.3 \mathrm{kDa}$ exerted the strongest suppression. The action phase assay showed that LUPP- 3 could bind with the viral particles and prevented ALV-J adsorption onto the host cells. And the ALV-J relative gene and gp 85 protein expression were significantly suppressed after being administration with LUPP-3. Therefore, the low Mw polysaccharides from U. pertusa have great potential as an anti-ALV-J drug alternative.
\end{abstract}

\section{Introduction}

Avian Leukosis Virus Subgroup J (ALV-J) is an oncogenic retrovirus [1] which was first isolated in the UK in 1988 from meat-type chicken [2]. ALV-J often induced immunosuppression, high mortality, and growth retardation and leads to a variety of tumors such as hemangioma and myeloid leucosis $[3,4]$. In the early to mid-1990s, an outbreak was observed in Japan, USA, Argentina, and other European countries, and it also spread to Malaysia and China by the early 2000s [5]. Although the eradication of breeding flocks against ALV-J was successful in some areas, the widespread distribution of ALV-J and the diverse culture model of poultry industry made it difficult to prevent and control ALV-J, which had caused severe economic losses in poultry industry worldwide $[6,7]$. Until now, commercial vaccines and drugs are still not available against ALV-J infection [8,9]. Therefore, it is necessary to find effective drugs or vaccines to control ALV-J spread.

Algae has received much attention because of the production of high-value products [10]. The products from the cell wall of marine algae include sulfated polysaccharides, such as fucoidan and carrageenan from brown and red seaweed, respectively [11]. Ulva belongs to Family Ulvaceae, Class Chlorophyceae, and Chlorophyta Division [12]. Polysaccharide is one of the important bioactive compounds in Ulva. The mainly repeating disaccharide units of Ulva polysaccharide are $[\beta$-D-Glcp A- $(1 \longrightarrow 4)-\alpha$-L-Rhap $3 S]$ and $[\alpha$-L-Idop 
A-(1 $\longrightarrow 4)-\alpha$-L-Rhap 3S] [13]. And it has already proven to be a remarkable polysaccharide with multiple biological activity. For example, Qi et al. obtained several polysaccharides from Ulva pertusa and found that high sulfate content samples had more effective hydroxyl radical scavenging activity and stronger reducing power than natural ones [14]. Further, Thanh et al. isolated U. lactuca polysaccharides and demonstrated that the polysaccharide had a significant cytotoxic activity against three cancer cell lines: HepG2 (hepatocellular carcinoma), MCF7 (human breast cancer), and Hela (cervical cancer) [15]. In addition, in vitro and in vivo studies showed that the sulfated polysaccharides from Ulva exhibit anticoagulant, antibacterial, antiproliferative, antihyperlipidemic, and immune-modulatory activities [16-20]. Scientists also studied the antiviral activities of the polysaccharides from Ulva. Reports showed that the Ulva polysaccharide had anti-HSV1, Japanese encephalitis virus, white spot syndrome virus, etc. [21-23]. However, the researches of Ulva polysaccharide focusing on poultry viruses were few.

The high molecular weight $(\mathrm{Mw})$ of polysaccharides limited their application due to their physical properties such as low solution in water and high viscosity which decreased their biological activity [24]. In comparison, low Mw algae polysaccharide was degraded by various methods from high Mw polysaccharide [25-27] and it has higher water solubility and stability and easy organism absorption [28]. Recently, it was reported that the low Mw polysaccharides extracted from algae carried some effects on the inhibition of HIV, HSV-1, and $\mathrm{H} 1 \mathrm{N1}$ virus [29-31]. However, the studies aimed at finding the effects against ALV-J of algal polysaccharides were scarce. So, the applications of low Mw polysaccharides from Ulva in preventing ALV-J infection would be promising and innovative.

In our experiment, $U$. pertusa polysaccharides (UPPs) were extracted by traditional hot water extraction; then, hydrogen peroxide $\left(\mathrm{H}_{2} \mathrm{O}_{2}\right)$ oxidative degradation method was used to prepare several low Mw U. pertusa polysaccharides (LUPPs) and the chemical composition of LUPPs was determined. Meanwhile, the effects of different degradation conditions (including $\mathrm{pH}$, temperature, and $\mathrm{H}_{2} \mathrm{O}_{2}$ concentration) on Mw of UPP were also explored. Finally, the antiALV-J activity of LUPPs was tested in vitro. The results of this study would provide theoretical basis for exploration and development of algal polysaccharides as a new strategy in control of the ALV-J.

\section{Materials and Methods}

2.1. Reagents and Seaweeds Samples. U. pertusa was collected from the number 1 bathing beach of Qingdao, China, in April 2016. After washing with tap water, the algae was dried at $50^{\circ} \mathrm{C}$ to constant weight and stored at room temperature before being used. All reagents used were of analytical grade.

2.2. Extraction of UPP. UPP was extracted by hot water extraction and alcohol precipitation method reported by Zhang et al. [32] with some modification. Briefly, $30 \mathrm{~g}$ of dried algae was mixed with $1.2 \mathrm{~L}$ of distilled water and maintained at $125^{\circ} \mathrm{C}$ for $4 \mathrm{~h}$. Then, the mixture was filtered and the supernatant was condensed by a rotary evaporator. The solution was dialyzed against distilled water for $48 \mathrm{~h}$ using dialysis tube with a $3.5 \mathrm{kDa} \mathrm{Mw}$ cut-off. After condensing again, 3-fold volume anhydrous ethanol was added to the dialyzed solution. The mixture was placed overnight at $4^{\circ} \mathrm{C}$ and then centrifuged. The precipitate was lyophilized and referred to as UPP. The yield (\%) of the UPP was calculated by the formula: yield = (polysaccharides weight/algal dry weight).

2.3. Degradation of UPP. UPP was dissolved in distilled water in concentration of $20 \mathrm{mg} / \mathrm{mL}$. The solutions were heated in a water bath with stirring at different $\mathrm{H}_{2} \mathrm{O}_{2}$ concentration and desired $\mathrm{pH}$ condition. Every $30 \mathrm{~min}, 0.5 \mathrm{~mL}$ of the reaction mixture was removed for high performance gel permeation chromatography (HPGPC) to investigate the effect of $\mathrm{pH}$, $\mathrm{H}_{2} \mathrm{O}_{2}$ concentration, and temperature on the UPP degradation. Finally, according to the above results, LUPPs were prepared under different conditions.

2.4. Chemical Characterization. HPGPC method was used to measure the Mw of UPP and LUPPs with a TSK gel G3000PWxl column. The samples were detected by a refractive index detector, using $0.1 \mathrm{~mol} / \mathrm{L} \mathrm{Na}_{2} \mathrm{SO}_{4}$ as the mobile phase, and the flow rate was $0.5 \mathrm{~mL} / \mathrm{min}$ also with a column temperature of $35^{\circ} \mathrm{C}$. Dextran standards (Mw 1000, 5000, $12000,50000,80000$, and 270000, Sigma, USA) were used to calibrate the column.

The protein content was analyzed by Bradford's method [33] using bovine serum albumin (BSA) as the standard. Phenol-sulfuric acid method [34] was used to detect the total sugar content and using rhamnose as the standard. Barium chloride gelatin method [35] was used to determine sulfate content. The FT-IR spectra of samples were measured in a KBr pellet by Nicolet-360 FT-IR spectrometer.

2.5. Cells, Virus, and Antibodies. The NX0101 strain of ALV-J, ALV-J gp85-specific monoclonal antibody, and DF-1 cell line were kindly gifted by Professor Cheng, Shandong Agricultural University. Dulbecco's modified Eagle's medium (DMEM) supplemented with $1 \%(\mathrm{v} / \mathrm{v})$ or $10 \%(\mathrm{v} / \mathrm{v})$ fetal bovine serum (FBS) was the maintenance medium (MM) or growth medium (GM), respectively. The ALV-J was titrated by quantifying the tissue culture infectious dose $50\left(\mathrm{TCID}_{50}\right)$ using the Reed-Muench formula.

2.6. Cytotoxicity Test. The cytotoxicity of UPP and LUPPs on DF-1 cells was evaluated by an MTT (3-(4, 5-dimethyl2-thiazolyl)-2,5-diphenyl-2-H-tetrazolium bromide) assay. Briefly, DF-1 cell monolayers grown in triplicate in 96well plate were supplied with $100 \mu \mathrm{L}$ MM which contained the indicated polysaccharides (from $2 \mathrm{mg} / \mathrm{mL}$ to $0.03125 \mathrm{mg} / \mathrm{mL}$ ), and the cells that were supplied with $100 \mu \mathrm{L}$ $\mathrm{MM}$ without polysaccharides were set as the cell control. The supernatant was removed after $24 \mathrm{~h}$ incubation; then the cell was added with $20 \mu \mathrm{L}$ MTT and maintained for another $4 \mathrm{~h}$. Later, the MTT was discarded and $100 \mu \mathrm{L}$ DMSO was added. Subsequently, the absorbance was read at the wavelength of $490 \mathrm{~nm}$ using a plate reader (iMark ${ }^{\mathrm{TM}}$ Bio-Rad). The cytotoxic 
activity was calculated by the following equation: survival rate $(\%)=(\mathrm{Ae} / \mathrm{Ac}) \times 100 \%$, where Ae and Ac were the absorbance of experimental group (Ae) and cell control (Ac), respectively.

\subsection{Antivirus Test In Vitro}

2.7.1. ALV p27 Antigen Detection. DF-1 cells seeded in 96well plate were adsorbed with 100 TCID $_{50}$ of ALV-J and mixed with the indicated polysaccharides dissolved in MM at a final concentration of $2 \mathrm{mg} / \mathrm{mL}$ for $2 \mathrm{~h}$ at $37^{\circ} \mathrm{C}$. Next, the polysaccharides and the virus were washed away and the cells were covered with $2 \mathrm{mg} / \mathrm{mL}$ corresponding polysaccharides that dissolved in MM. Meanwhile, the DF-1 cells that were not infected with ALV-J and the cells that were not exposed to the polysaccharides were set as the cell control and virus control. After $24 \mathrm{~h}$ incubation at $37^{\circ} \mathrm{C}$, the viral titers were measured by the ALV p27 antigen test kit (IDEXX, USA). The relative expressions of ALV p27 antigen were represented by the formula: $\mathrm{S} / \mathrm{P}=$ (Sample mean-Negative control mean)/ (Positive control mean-Negative control mean), and the negative control and positive control were provided by the kit.

2.7.2. Polysaccharides Action Stage Assay. Before Adsorption (BA). The MM containing $1 \mathrm{mg} / \mathrm{mL}$ polysaccharides was added to DF-1 cell monolayers and incubated for $2 \mathrm{~h}$. Then, the cells were washed with PBS and inoculation with 100 $\mathrm{TCID}_{50}$ of ALV-J at $37^{\circ} \mathrm{C}$ for $2 \mathrm{~h}$. After incubation, the unadsorbed viruses were washed away and the cells were covered with simple MM for $24 \mathrm{~h}$.

Adsorption (Ad). DF-1 cells were infected with 100 TCID $_{50}$ of ALV-J and mixed with the indicated polysaccharides that dissolved in $\mathrm{MM}$ at a final concentration of $1 \mathrm{mg} / \mathrm{mL}$. After incubation at $4^{\circ} \mathrm{C}$ for $2 \mathrm{~h}$, the cells were washed with PBS and then incubated in MM for $24 \mathrm{~h}$.

After Adsorption (AA). After being incubated with 100 TCID $_{50}$ of ALV-J for $2 \mathrm{~h}$, the DF-1 cells were washed by PBS and incubated with MM containing polysaccharides at a concentration of $1 \mathrm{mg} / \mathrm{mL}$ for $24 \mathrm{~h}$.

Later, all supernatants were collected. And ALV p27 antigen test kit was used to determine the viral titers.

2.7.3. ALV-J Gene Relative Expression and Protein Expression. DF-1 cells were seeded in 12-well plate, infected with 100 TCID $_{50}$ of ALV-J, and mixed with the polysaccharides that dissolved in $\mathrm{MM}$ at indicated concentration for $2 \mathrm{~h}$ adsorption at $37^{\circ} \mathrm{C}$. Then the cells were washed with PBS, covered by $\mathrm{MM}$, and incubated at $37^{\circ} \mathrm{C}$ with $5 \% \mathrm{CO}_{2}$ for about $24 \mathrm{~h}$.

Real-Time PCR. Real-time PCR were used to determine the ALV-J gene relative expression in DF-1 cells. In brief, the total RNA of the treated DF-1 cells were extracted by RNAprep Pure Cell/Bacteria Kit (TIANGEN BIOTECH Co. Ltd., Beijing, China). Then PrimeScript ${ }^{\mathrm{TM}} \mathrm{RT}$ reagent Kit and SYBR $^{\circledR}$ Premix ExTaq ${ }^{\mathrm{TM}}$ Kit (Takara BIO Inc., Liaoning, China) were used for reverse transcription and real-time PCR. The forward and reverse primers for ALV-J were $5^{\prime}$ - TGCGTGCGTGGTTATTATTTC-3' and 5'-AATGGTGAGGTCGCTGACTGT-3' ${ }^{\prime}$, respectively; and the forward and reverse primer for internal control GAPDH were
$5^{\prime}$-GAA-CATCATCCCAAGCGTCCA- $3^{\prime}$ and $5^{\prime}$-CGGCAGGTCAGGTCAACAAC- $3^{\prime}$. The real-time PCR were performed at $95^{\circ} \mathrm{C}$ for $30 \mathrm{~s}, 95^{\circ} \mathrm{C}$ for $5 \mathrm{~s}$ and $60^{\circ} \mathrm{C}$ for $34 \mathrm{~s}(34$ cycles), $95^{\circ} \mathrm{C}$ for $15 \mathrm{~s}$, and $60^{\circ} \mathrm{C}$ for $60 \mathrm{~s}$ [36].

Western Blot. After $24 \mathrm{~h}$ incubation, the cells were lysed and protein concentrations were determined with a BCA protein assay kit (Beyotime Biotechnology). Protein samples were separated by SDS-PAGE and transferred to $0.45 \mu \mathrm{m}$ PVDF membrane (Millipore) for Western analysis. The membrane was blocked with $5 \%$ nonfat milk in TBST buffer (20 mM Tris- $\mathrm{HCl}, 500 \mathrm{mM} \mathrm{NaCl}, 0.1 \%$ Tween 20) for $1 \mathrm{~h}$ at room temperature and incubated with mouse ALV-J gp85specific monoclonal antibody overnight at $4^{\circ} \mathrm{C}$. Then, membrane was incubated with horseradish peroxidase- (HRP-) conjugated secondary antibodies for $1 \mathrm{~h}$ at room temperature and visualized using ECL reagents. The densities of the protein bands were normalized to that of $\beta$-tubulin, which served as an inner control.

Indirect Immunofluorescence Assay (IFA). The DF-1 cells were incubated for 5 days at $37^{\circ} \mathrm{C}$ after inoculation. The cells were washed with PBS and added with cold acetone and ethanol (3:2 for v/v) for about $10 \mathrm{~min}$ and then washed with PBS again followed by being treated with the gp85-specific monoclonal antibody overnight at $4^{\circ} \mathrm{C}$. Afterwards, the cells were washed thoroughly with $\mathrm{PBS}$ and incubated with goat anti-mouse IgG-FITC at $37^{\circ} \mathrm{C}$ for $1 \mathrm{~h}$. After washing, the cells were directly observed using an inverted fluorescence microscope.

2.8. Statistical Analysis. SPSS were used to perform the statistical analysis and the differences between groups were analyzed by one-way ANOVA.

\section{Results}

\subsection{Influence of Degradation Condition on the Mw of UPP}

3.1.1. Effect of $p H$. As the results showed in Figure 1, in $30 \mathrm{~min}$, the Mw was relatively close and decreased to $41 \mathrm{kDa}$ and $42 \mathrm{kDa}$, respectively, when the $\mathrm{pH}$ was 4 and 8 . But, after $30 \mathrm{~min}$, the degradation for $\mathrm{pH} 8$ groups was slower than $\mathrm{pH}$ 4 gradually. Compared with $\mathrm{pH} 4$ and 8, before $90 \mathrm{~min}$, the degradation curves were closer as well when $\mathrm{pH}$ decreased to 3,2 , and 1 , and Mw of UPP was $28 \mathrm{kDa}, 27 \mathrm{kDa}$, and $28 \mathrm{kDa}$ at $90 \mathrm{~min}$, respectively. Subsequently, degradation became different and the final degradation results were $10 \mathrm{kDa}$, $13 \mathrm{kDa}$, and $20 \mathrm{kDa}$, respectively. The results showed that the Mw of UPP was nearly the same at the beginning of the degradation. And the difference among different $\mathrm{pH}$ groups increased with the time going on. Generally, the lower $\mathrm{pH}$ is, the lower Mw polysaccharides were obtained.

3.1.2. Effect of $\mathrm{H}_{2} \mathrm{O}_{2}$ Concentration. Figure 2 showed the Mw changes of UPP at different $\mathrm{H}_{2} \mathrm{O}_{2}$ concentration. The $\mathrm{Mw}$ changed to $54 \mathrm{kDa}, 35 \mathrm{kDa}, 32 \mathrm{kDa}, 26 \mathrm{kDa}$, and $24 \mathrm{kDa}$ corresponding to original $\mathrm{H}_{2} \mathrm{O}_{2}$ concentration of $0.15 \%$, $0.3 \%, 1.5 \%, 3.0 \%$, and $4.5 \%$ at $60 \mathrm{~min}$, respectively. The Mw decreased with the degradation proceeding, and the final Mw values of the degraded polysaccharides were $21 \mathrm{kDa}$, 
TABLE 1: Degradation conditions and yield of LUPPs.

\begin{tabular}{lccccc}
\hline Sample & Temperature $\left({ }^{\circ} \mathrm{C}\right)$ & $\mathrm{pH}$ & $\mathrm{H}_{2} \mathrm{O}_{2}(\%)$ & Time $(\mathrm{min})$ & Yield $(\%)$ \\
\hline LUPP-1 & 70 & 4 & 3 & 45 & 58.22 \\
LUPP-2 & 80 & 4 & 3 & 125 & 39.02 \\
LUPP-3 & 90 & 4 & 3 & 90 & 17.60 \\
LUPP-4 & 100 & 4 & 3 & 90 & 22.65 \\
\hline
\end{tabular}

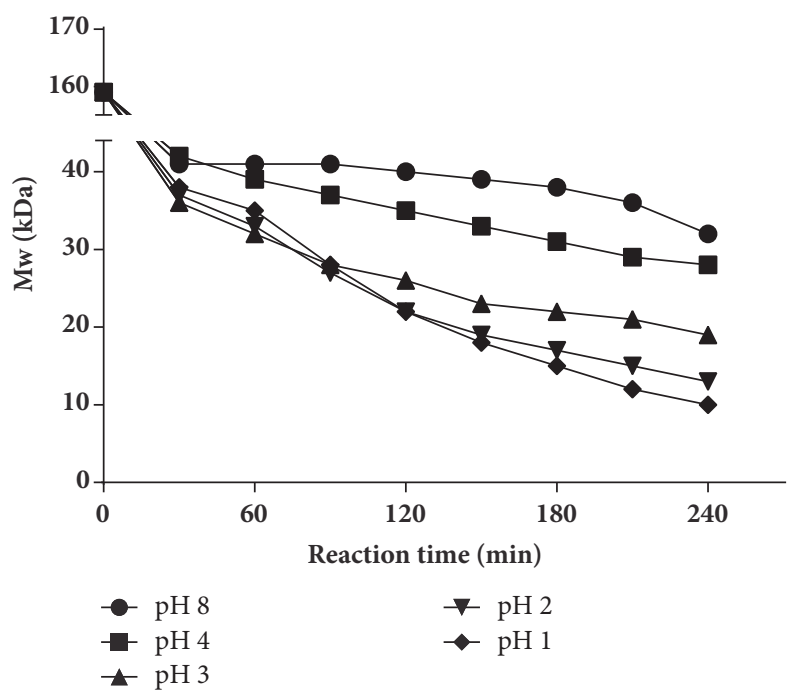

FIGURE 1: Effect of $\mathrm{pH}$ on degradation of UPP. UPP was degraded in $0.3 \% \mathrm{H}_{2} \mathrm{O}_{2}$ at $80^{\circ} \mathrm{C}$ and $\mathrm{pH}$ values of $1,2,3,4$, and 8 were tested.

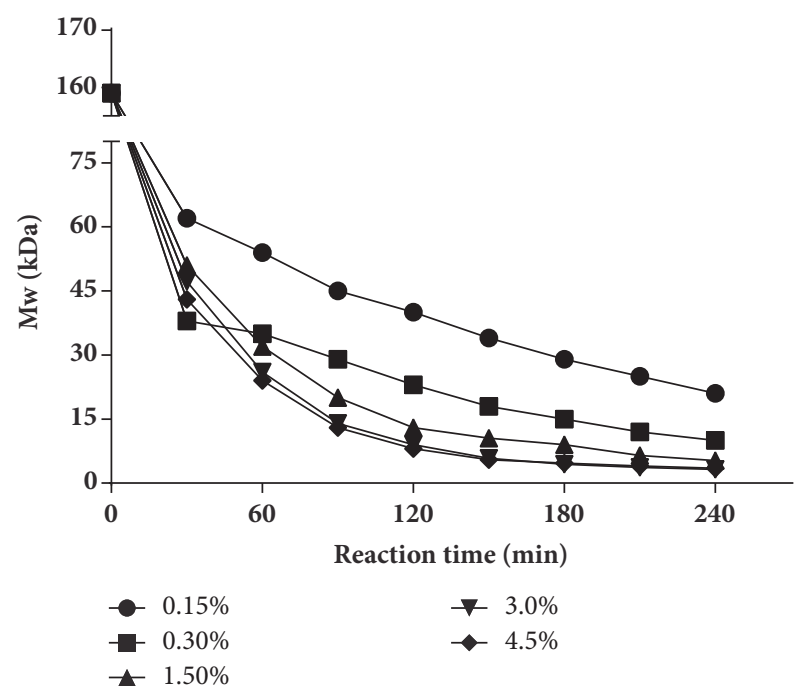

FIGURE 2: Effect of $\mathrm{H}_{2} \mathrm{O}_{2}$ concentration on degradation of UPP. The reaction temperature was $80^{\circ} \mathrm{C}$ and $\mathrm{pH} 4$ was used. Different $\mathrm{H}_{2} \mathrm{O}_{2}$ concentrations varying from $0.15 \%$ to $4.5 \%$ were tested.

$10 \mathrm{kDa}, 5.3 \mathrm{kDa}, 3.5 \mathrm{kDa}$, and $3.2 \mathrm{kDa}$, respectively. Moreover, the curves of $3.0 \%$ and $4.5 \%$ groups were similar from beginning to the end. The results illustrated that higher $\mathrm{H}_{2} \mathrm{O}_{2}$ concentrations were more favorable for degradation, and

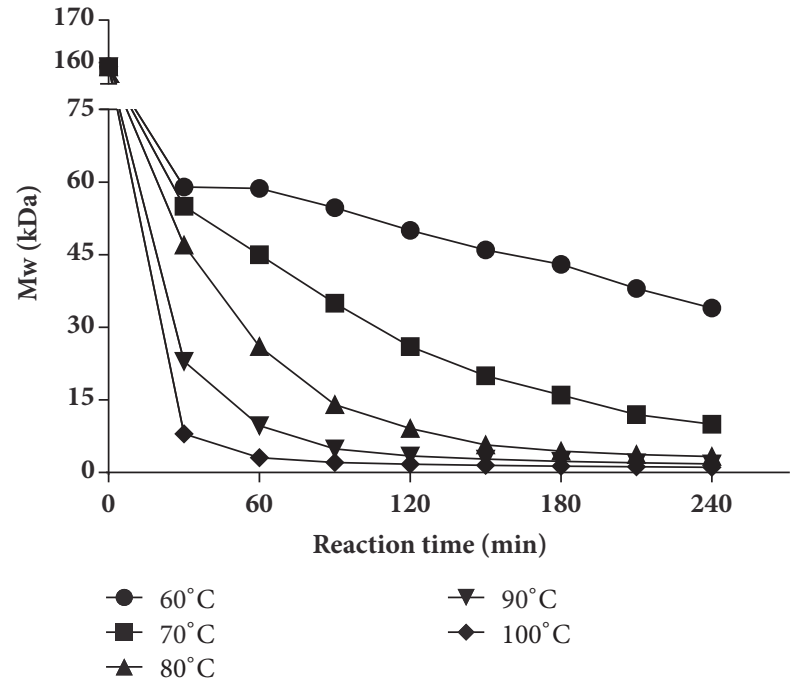

FIGURE 3: Effect of temperature on degradation of UPP. UPP was degraded in $\mathrm{pH} 4$ and $3 \% \mathrm{H}_{2} \mathrm{O}_{2}$. Temperatures from $60^{\circ} \mathrm{C}$ to $100^{\circ} \mathrm{C}$ were tested.

$3.0 \% \mathrm{H}_{2} \mathrm{O}_{2}$ was enough for degradation to obtain the low $\mathrm{Mw}$ polysaccharides.

3.1.3. Effect of Temperature. Figure 3 showed the degradation of the UPP under different temperature conditions. When the temperature was $60^{\circ} \mathrm{C}$, the $\mathrm{Mw}$ of the polysaccharide was $59 \mathrm{kDa}$ at $30 \mathrm{~min}$, and, finally, the Mw only decreased to $34 \mathrm{kDa}$, while the Mw of the polysaccharides in other four temperature groups showed more significant changes in the degradation process. For $70^{\circ} \mathrm{C}$ and $80^{\circ} \mathrm{C}$, the $\mathrm{Mw}$ values were around $10 \mathrm{kDa}$ and $3.3 \mathrm{kDa}$ at $240 \mathrm{~min}$, significantly lower than that of $60^{\circ} \mathrm{C}$ group. The $\mathrm{Mw}$ of the polysaccharides sharply decreased to $23 \mathrm{kDa}$ and $8 \mathrm{kDa}$ at $30 \mathrm{~min}$ when the temperatures were $90^{\circ} \mathrm{C}$ and $100^{\circ} \mathrm{C}$; later, the degradation slowed down and the curves tended to stay with the polysaccharides Mw of $1.8 \mathrm{kDa}$ and $1.1 \mathrm{kDa}$ at last. The results revealed that higher temperature could accelerate the degradation.

\subsection{Chemical Analysis and Preparation of LUPP}

3.2.1. Preparation of LUPP. According to the above results of $\mathrm{H}_{2} \mathrm{O}_{2}$ oxidative degradation on UPP, several kinds of LUPPs with different $\mathrm{Mw}$ were prepared by a series of conditions. After degradation, the LUPP solutions were neutralized to $\mathrm{pH}$ 7 and dialyzed in distilled water for about $48 \mathrm{~h}$. Then the solutions were filtered and freeze-dried. The specific preparation conditions are presented in Table 1. 
TABLE 2: Properties of the polysaccharides (\%w/w of dry weight). Values are as mean \pm standard deviation $(\mathrm{n}=3)$.

\begin{tabular}{lcccc}
\hline Sample & Mw $(\mathrm{kDa})$ & Total Sugar $(\%)$ & Sulfate $(\%)$ & Protein $(\%)$ \\
\hline UPP & $159 \pm 0.9$ & $44.61 \pm 1.20$ & $17.46 \pm 0.24$ & $1.12 \pm 0.01$ \\
LUPP-1 & $23.6 \pm 0.5$ & $42.49 \pm 0.65$ & $21.24 \pm 0.16$ & $0.76 \pm 0.01$ \\
LUPP-2 & $9.0 \pm 0.2$ & $38.77 \pm 0.69$ & $19.43 \pm 0.06$ & $0.19 \pm 0.01$ \\
LUPP-3 & $4.3 \pm 0.3$ & $37.59 \pm 0.44$ & $20.18 \pm 0.24$ & $0.17 \pm 0.01$ \\
LUPP-4 & $2.5 \pm 0.1$ & $33.40 \pm 0.35$ & $20.63 \pm 0.23$ & $0.28 \pm 0.01$ \\
\hline
\end{tabular}

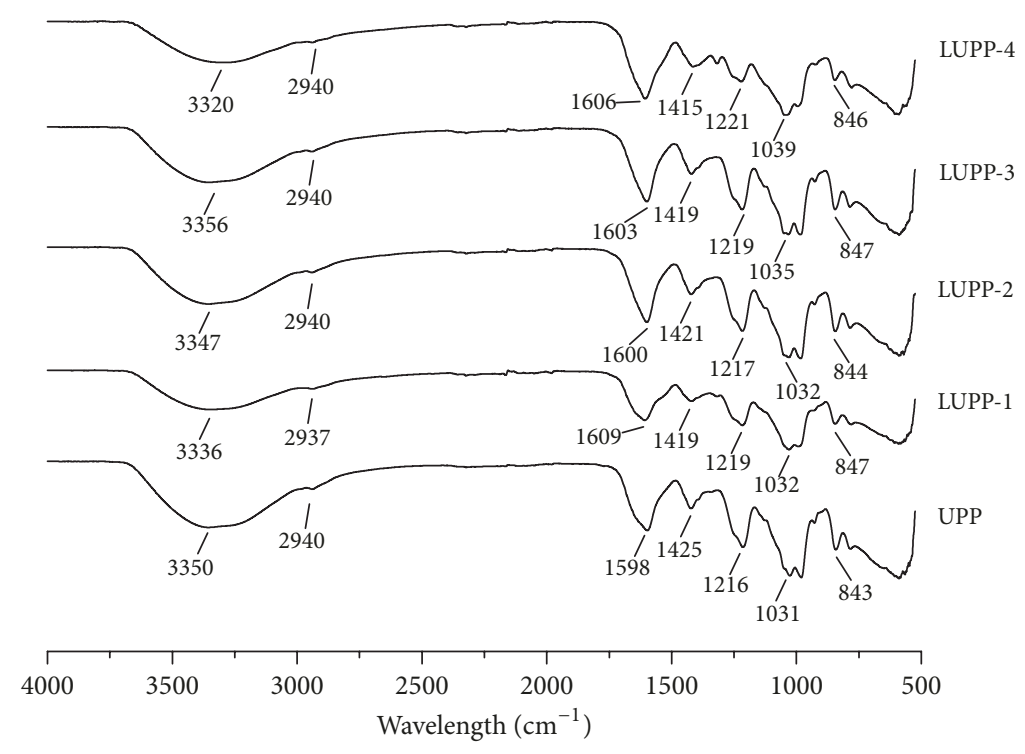

FIGURE 4: FT-IR spectra of UPP and LUPPs.

3.2.2. Chemical Characterization. Based on the methods described in Section 3.2.1, four kinds of LUPPs were prepared. The chemical composition and FT-IR spectra of initial UPP and LUPPs are shown in Table 2 and Figure 4. The chromatograms of Dextran standards, UPP, and LUPPs are given in Figure S1-S11 in the Supplementary Materials. The HPLC standard curve equation was $\mathrm{y}=-2.4616 \mathrm{x}+24.507$ with the elution time as the ordinate and Log Mw as the abscissa. According to the above equation, the Mw of UPP and LUPPs were $159 \mathrm{kDa}, 23.6 \mathrm{kDa}, 9.0 \mathrm{kDa}, 4.3 \mathrm{kDa}$, and $2.5 \mathrm{kDa}$, respectively. UPP possessed the highest total sugar content for about $44.61 \%$, and the total sugar content decreased with the decrease of Mw. But the sulfate content was about $20 \%$ for all samples. UPP also had the highest protein content, only $1.12 \%$, and the protein content decreased with the decrease of Mw among the samples.

Results of FT-IR spectra were shown in Figure 4. Typical absorption peaks at $3330 \mathrm{~cm}^{-1}$ and $2940 \mathrm{~cm}^{-1}$ represent $\mathrm{O}-\mathrm{H}$ and $\mathrm{C}-\mathrm{H}$ stretching vibration. The $\mathrm{C}=\mathrm{O}$ asymmetric and symmetric stretching vibration appear at $1600 \mathrm{~cm}^{-1}$ and $1420 \mathrm{~cm}^{-1}$, respectively. Absorption at $1030 \mathrm{~cm}^{-1}$ indicates $\mathrm{C}-\mathrm{O}-\mathrm{H}$ deformation vibration. Featured absorption at $1220 \mathrm{~cm}^{-1}$ corresponds to $\mathrm{S}=\mathrm{O}$ stretching vibration and the peaks at $845 \mathrm{~cm}^{-1}$ might reflect $\mathrm{C}-\mathrm{O}-\mathrm{S}$ symmetry stretching vibration $[37,38]$. Generally speaking, the absorption peaks for all the groups were similar which indicated that the degradation did not significantly affect the chemical structure of the polysaccharides.

3.3. Cytotoxicity. MTT assay was applied to estimate the safe concentration of UPP and LUPPs. According to previous reports $[39,40]$, the polysaccharides were considered to have no cytotoxic activity when the cell survival rate is over $85 \%$. As the results showed in Table 3, in general, all of the cell relative survival rates were over $95 \%$ at the concentration $2 \mathrm{mg} / \mathrm{mL}$; therefore, $2 \mathrm{mg} / \mathrm{mL}$ of all the polysaccharides was still safe for further study.

\subsection{Antiviral Activity}

3.4.1. ALV p27 Antigen Detection. Figure 5 showed the relative expression of ALV p27 antigen that was determined by ELISA method. The ALV p27 antigen expression was decreased for all the polysaccharides groups when treated with $2 \mathrm{mg} / \mathrm{mL}$ sample solutions, and it was significantly lower than that of the virus control. The S/P value of LUPP-2 was 0.153 and higher than that of the UPP (0.132) and LUPP1 (0.131). In addition, the S/P value of LUPP-4 was not significantly different from the other experimental groups, except LUPP-3, indicating that the anti-ALV-J effect was not correlated with Mw simply. Among all the samples, the LUPP-3 with Mw of $4.3 \mathrm{kDa}$ featured the lowest p27 relative 
TABLE 3: Relative Survival Rate of DF-1 cells. Values are as mean \pm standard deviation $(\mathrm{n}=3)$.

\begin{tabular}{|c|c|c|c|c|c|c|c|}
\hline Concentration $(\mathrm{mg} / \mathrm{mL})$ & 2 & 1 & 0.5 & 0.25 & 0.125 & 0.0625 & 0.03125 \\
\hline UPP & $0.96 \pm 0.02$ & $1.03 \pm 0.04$ & $1.02 \pm 0.03$ & $1.09 \pm 0.05$ & $1.01 \pm 0.06$ & $0.96 \pm 0.04$ & $1.06 \pm 0.04$ \\
\hline LUPP-1 & $0.95 \pm 0.01$ & $1.09 \pm 0.02$ & $1.00 \pm 0.04$ & $1.01 \pm 0.05$ & $0.96 \pm 0.07$ & $1.10 \pm 0.04$ & $1.04 \pm 0.06$ \\
\hline LUPP-2 & $0.94 \pm 0.04$ & $1.09 \pm 0.03$ & $1.07 \pm 0.01$ & $1.08 \pm 0.05$ & $1.05 \pm 0.02$ & $0.97 \pm 0.03$ & $1.06 \pm 0.04$ \\
\hline LUPP-3 & $0.95 \pm 0.03$ & $1.11 \pm 0.05$ & $1.04 \pm 0.05$ & $1.07 \pm 0.01$ & $1.11 \pm 0.08$ & $0.96 \pm 0.07$ & $1.11 \pm 0.04$ \\
\hline LUPP-4 & $0.99 \pm 0.03$ & $0.98 \pm 0.06$ & $1.06 \pm 0.04$ & $0.98 \pm 0.02$ & $1.09 \pm 0.05$ & $1.04 \pm 0.04$ & $0.99 \pm 0.05$ \\
\hline
\end{tabular}

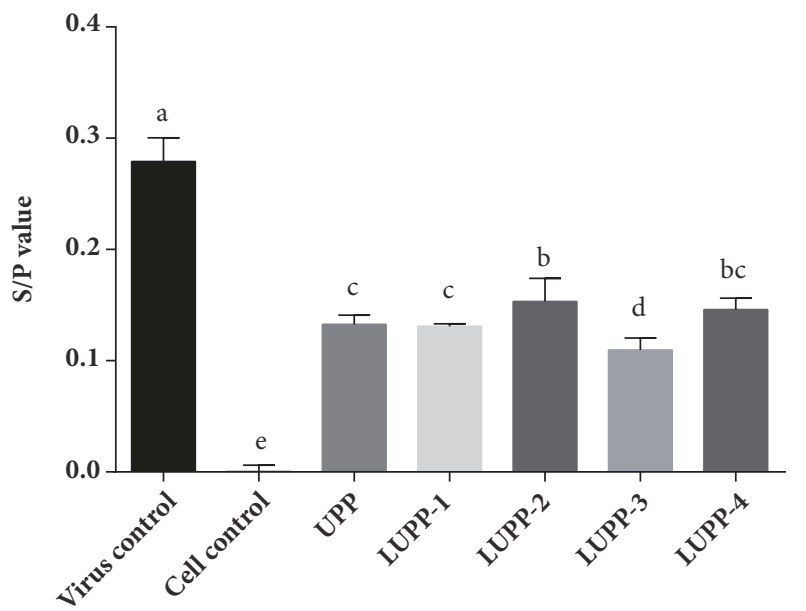

FIGURE 5: Relative expression of ALV p27 antigen. After being treated with ALV-J and polysaccharides for $2 \mathrm{~h}$ simultaneously, the cells were washed by PBS and incubated with MM with corresponding polysaccharides for $24 \mathrm{~h}$. Values represent mean + standard deviation $(n=3)$. Statistical significance $\mathrm{p}<0.05$, compared with each other.

expression, whose S/P value was only 0.110 . Thus, LUPP-3 was cautiously chosen for further experiments.

3.4.2. Action Phase of the Polysaccharides. To explore the function time point of the polysaccharides, LUPP-3 was tested in different administration. And ELISA was used to determine the antiviral effect. The results presented in Figure 6 showed that the S/P values of BA (before adsorption) and AA (after adsorption) groups were both 0.224 , which were not significantly lower than the virus control (0.244). However, the $\mathrm{S} / \mathrm{P}$ value of Ad administration was 0.180 , significantly lower than the virus control. Therefore, the above results indicated that the LUPP-3 could inhibit virus attachment to the cells; nevertheless, it could not take effect in the stage before virus adsorption or after the virus penetrated into the cells.

3.4.3. RT-PCR Assay. As the results illustrated in Figure 7, the gene relative expression of ALV-J decreased gradually with the increase of LUPP-3 concentration. Treatment with $1000 \mu \mathrm{g} / \mathrm{mL}$ and $200 \mu \mathrm{g} / \mathrm{mL}$ showed a strong suppression against ALV-J adsorption and the gene expression was 35.91 and 58.22, significantly lower than the virus control (82.49). However, when treated with $40 \mu \mathrm{g} / \mathrm{mL}$ LUPP-3, the gene

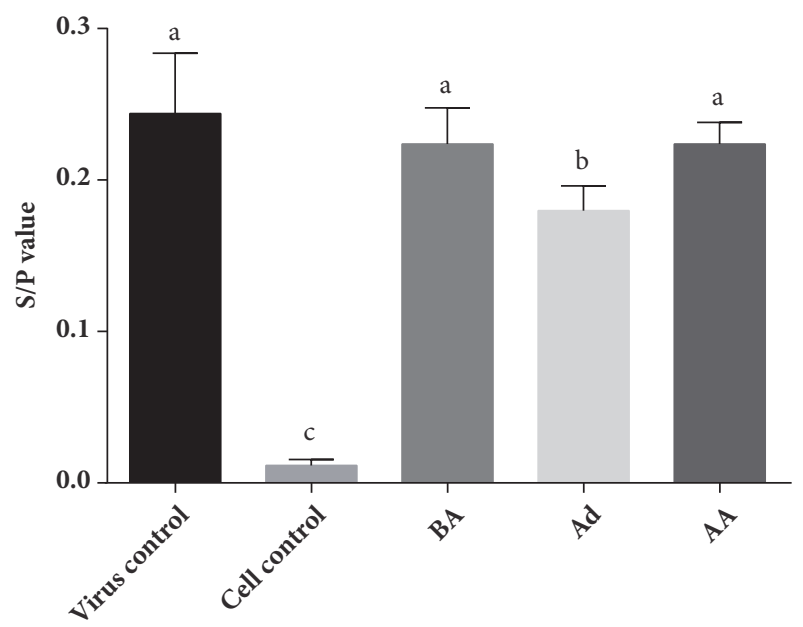

FIGURE 6: p27 expression of different modes of administration detected by ELISA. BA: DF-1 cells handled with polysaccharides before virus adsorption; Ad: DF-1 cells handled with polysaccharides at the virus adsorption phase; AA: DF-1 cells handled with polysaccharides after virus adsorption. Values represent mean + standard deviation $(n=3)$. Statistical significance $\mathrm{p}<0.05$, compared with each other.

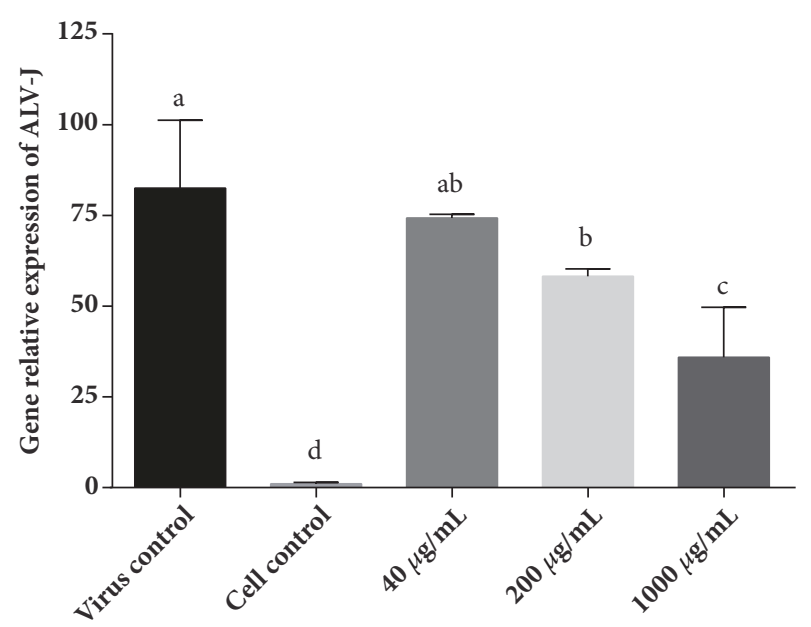

FIGURE 7: Gene relative expression of ALV-J. DF-1 cells inoculated with ALV-J and polysaccharides of different concentration for $2 \mathrm{~h}$ simultaneously. Then the cells were washed by PBS and covered with MM for $24 \mathrm{~h}$. After that, the cells were collected for RT-PCR assay. Values represent mean + standard deviation $(n=3)$. Statistical significance $\mathrm{p}<0.05$, compared with each other. 


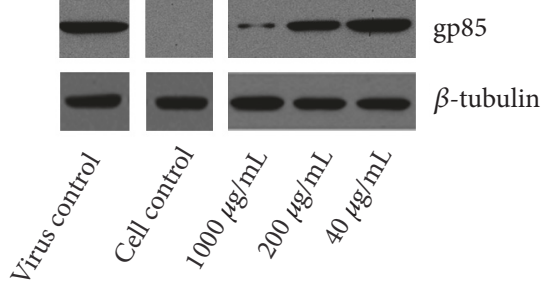

FIGURE 8: Western-blot analysis of ALV-J gp85 protein expression. DF-1 cells inoculated with ALV-J and polysaccharides of different concentration for $2 \mathrm{~h}$ simultaneously. Then the cells were washed by PBS and covered with MM for $24 \mathrm{~h}$. After that, the cells were collected and lysed for western-blot assay.

expression was 74.29 , lower than the virus control but the difference was not significant. The results illustrated that LUPP-3 showed a better inhibition against ALV-J in a medium or high concentration, and it was not desirable in a low concentration.

3.4.4. Determination of ALV-J gp85 Protein. To further verify the antiviral effect of LUPP-3, western blot and IFA were used to determine the protein expression of ALV-J. As the results of western blot showed in Figure 8, similar to the RT-PCT results, the antiviral effects were dose dependent. Expressions of gp85 protein were suppressed when administrated with $1000 \mu \mathrm{g} / \mathrm{mL}$ and $200 \mu \mathrm{g} / \mathrm{mL}$ LUPP-3, and the suppression of $1000 \mu \mathrm{g} / \mathrm{mL}$ treatment group was more significant. While treating with $40 \mu \mathrm{g} / \mathrm{mL}$ LUPP-3, the gp85 protein expression was similar to the virus control.

In IFA assay, the green fluorescence intensity could generally reflect the number of ALV-J. As the results showed in Figure 9, the fluorescence intensity of $40 \mu \mathrm{g} / \mathrm{mL}$ group was the strongest, which was similar with the virus control. In addition, different from the RT-PCR and western-blot results, the $200 \mu \mathrm{g} / \mathrm{mL}$ group also exhibited a strong fluorescence signal, which was the same with the results of virus control and $40 \mu \mathrm{g} / \mathrm{mL}$ group. However, the fluorescence intensity of $1000 \mu \mathrm{g} / \mathrm{mL}$ group was significantly weaker, which indicated that the ALV-J adsorption was effectively suppressed.

\section{Discussion}

Various methods are applied for degrading polysaccharides, such as chemical method [41], physical method [42], and enzymatic method [43] (Liu et al. 2017). Among them, the $\mathrm{H}_{2} \mathrm{O}_{2}$ oxidative degradation which belongs to chemical method is characterized by low cost and mild reaction, and it has been widely used in polysaccharides degradation. In the degradation process, the temperature, $\mathrm{pH}$ value, and $\mathrm{H}_{2} \mathrm{O}_{2}$ concentration were considered to have a great impact on the degradation. In this study, the degradation accelerated with the rising of the temperature and $\mathrm{H}_{2} \mathrm{O}_{2}$ concentration and with the decreasing of $\mathrm{pH}$, in general. Results of the $\mathrm{pH}$ experiment showed that each group produced similar product in $30 \mathrm{~min}$, and then the difference of the products' Mw between each group increased with the time going on. Eventually, the Mw of the products decreased with the decrease of $\mathrm{pH}$. $\mathrm{pH}$ affects the generation rate of free radical, thus affecting the degradation rate [44]. At the same time, the acidic environment provided by the low $\mathrm{pH}$ may also directly degrade the polysaccharide chain. However, the Mw of the product could not decrease to lower than $10 \mathrm{kDa}$ on $\mathrm{pH} 1$ condition, and we speculated that it might be due to the low temperature and $\mathrm{H}_{2} \mathrm{O}_{2}$ concentration. $\mathrm{H}_{2} \mathrm{O}_{2}$ concentration is also an important factor that affects UPP degradation. For example, Lee et al. degraded $\beta$-glucan on $0.5 \mathrm{mM}$ iron (II) sulfate heptahydrate $\left(\mathrm{FeSO}_{4} \cdot 7 \mathrm{H}_{2} \mathrm{O}\right)$ at $50^{\circ} \mathrm{C}$ for $1 \mathrm{~h}$ and found that the $\mathrm{Mw}$ of the product was $561.2 \mathrm{kDa}$ for $0.2 \% \mathrm{H}_{2} \mathrm{O}_{2}$ group, while the result decreased to $55.4 \mathrm{kDa}$ with $1.0 \% \mathrm{H}_{2} \mathrm{O}_{2}$ [45]. $\mathrm{H}_{2} \mathrm{O}_{2}$ could degrade polysaccharides by producing free radicals that would interrupt glycosides randomly in aqueous solutions [46]. In our study, the degradation was positively related to $\mathrm{H}_{2} \mathrm{O}_{2}$ concentration from the beginning, which might be due to the more free radicals generated by the higher $\mathrm{H}_{2} \mathrm{O}_{2}$ concentration. But the results of $3.0 \%$ and $4.5 \%$ concentration groups were similar, which suggest that $3.0 \% \mathrm{H}_{2} \mathrm{O}_{2}$ was enough for degradation. Another important factor in degrading UPP was temperature. Higher temperature means greater kinetic energy, allowing more collisions between molecules [47]. As shown in Figure 3, temperature had a great impact on degradation. A product of $8 \mathrm{kDa}$ could be obtained within $30 \mathrm{~min}$ at $100^{\circ} \mathrm{C}$. But, for $80^{\circ} \mathrm{C}$ and $90^{\circ} \mathrm{C}$ groups, it needs more than $120 \mathrm{~min}$ and $60 \mathrm{~min}$ to get the same Mw product, respectively. In addition, $60^{\circ} \mathrm{C}$ and $70^{\circ} \mathrm{C}$ groups could not produce the $8 \mathrm{kDa}$ product within $240 \mathrm{~min}$, eventually. Therefore, increasing temperature significantly accelerated the degradation.

According to the degradation results above, we prepared four LUPPs and determined their chemical composition preliminarily. Results showed that the total sugar content decreased with the decrease of the Mw, and we inferred that it might be due to the comprehensive reaction caused by the temperature, $\mathrm{H}^{+}$, and free radicals. Meanwhile, the protein content also decreased along with the decrease of Mw, which indicated that the degradation might benefit for protein removal. Additionally, the sulfate content was nearly the same and around $20 \%$ for all samples. The FT-IR spectra showed that UPP and LUPPs had similar characteristic peak, which implied that the degradation did not significantly change the chemical structure of UPP. And the featured adsorption at $845 \mathrm{~cm}^{-1}$ and $1220 \mathrm{~cm}^{-1}$ indicated that all samples were sulfated algae polysaccharides.

Since it was found in 1988, ALV-J has caused enormous economic loss to poultry breeding industry across the world $[48,49]$. However, because of the high mutation rate and the fact that the host factors that regulate viral infection are largely unknown [50], effective therapeutics are still not available for inhibiting ALV-J [8]. Eradicating the positive chickens was the only way to prevent ALV-J spread.

Until now, research on the anti-ALV-J activity of Ulva polysaccharides has not been reported. In this study, UPP and LUPPs were applied on ALV-J to investigate the antiviral effect for the first time. Results showed that the relative expression of ALV-J p27 antigen was significantly reduced on the presence of all samples. Effect of LUPP-3 with Mw of $4.3 \mathrm{kDa}$ was the best, and the inhibition of LUPP-2 and 


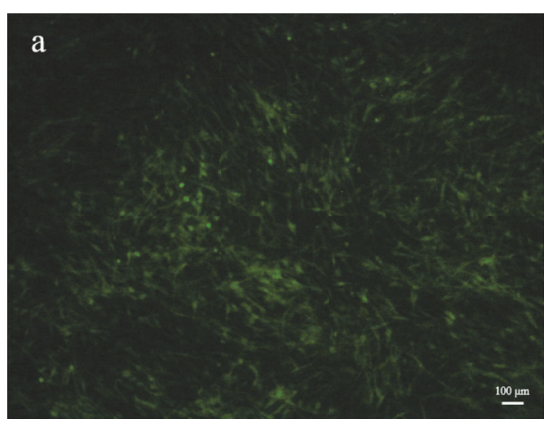

(a)

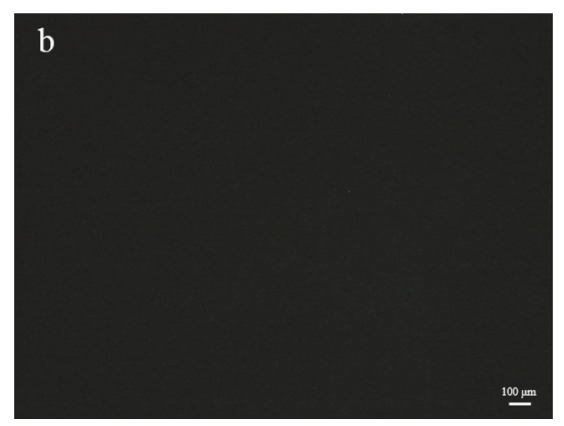

(b)

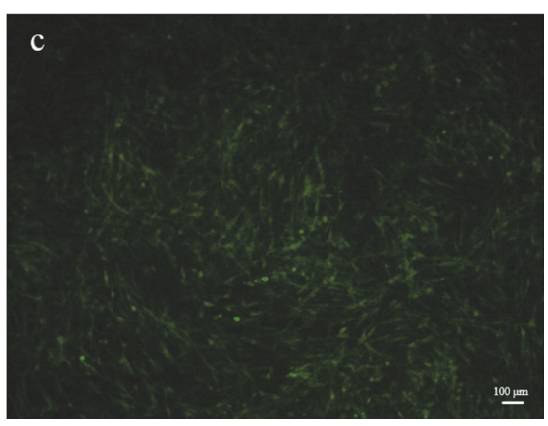

(c)

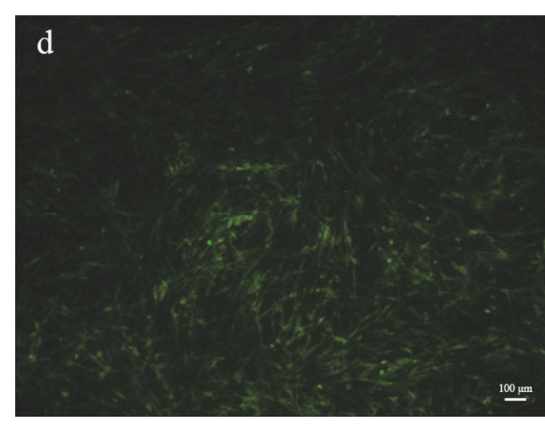

(d)

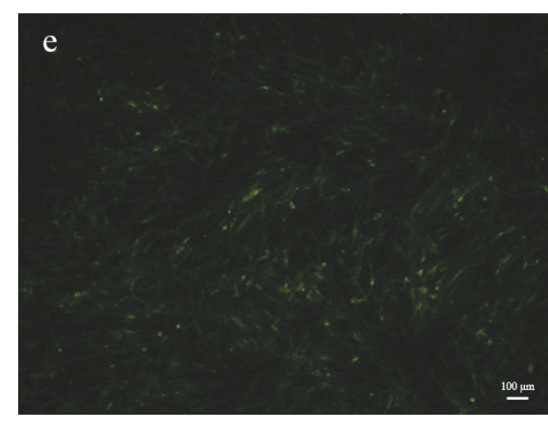

(e)

Figure 9: IFA analysis of ALV-J gp85 protein. DF-1 cells inoculated with ALV-J and polysaccharides of different concentration for $2 \mathrm{~h}$ simultaneously. Then the cells were washed by PBS and covered with MM for 5 days. After that, the IFA was carried out. (a) Virus control, (b) cell control, (c) ALV-J handled with $40 \mu \mathrm{g} / \mathrm{mL}$ LUPP-3, (d) ALV-J handled with $200 \mu \mathrm{g} / \mathrm{mL}$ LUPP-3, and (e) ALV-J handled with $1000 \mu \mathrm{g} / \mathrm{mL}$ LUPP-3.

LUPP-4 was weaker than that of UPP and LUPP-1, indicating that the antiviral activity was not only correlated with the Mw. Many studies have shown that the sulfate content of the polysaccharide has a great influence on its biological activities [51-53]. But, in our study, the sulfate content was nearly the same in all samples, and the antiviral effect exerted no relation with the total sugar content. Therefore, we deduced that the complicated suppression was probably caused by the comprehensive action that induced by Mw, sulfate, and some other factors. LUPP-3 might have a more suitable spatial structure to interact with the virus. Based on the above results, LUPP-3 was screened for subsequent experiments. To further explore the action stage of LUPPs, LUPP-3 was administrated in three different methods. Results revealed that the expression of p27 antigen decreased only with Ad treatment, which demonstrated that LUPP-3 could inhibit ALV-J adsorbtion on the host cells, and this effect might be achieved by the polysaccharides adsorption to the virus or to the cell surface specific receptors. Nevertheless, the polysaccharides had no inhibition when they were applied to DF-1 cells before inoculation (BA method), so we speculated that LUPP-3 could adsorb on the virus and form a viruspolysaccharides complex rather than adsorb onto the cell surface. The virus envelope sites which would contact with cell surface receptors were occupied by the polysaccharides, leading to the termination of virus invasion process. Some other types of algal polysaccharides were reported to act with the same mode as our samples. Carrageenan derivatives, for example, could bind to HSV virions by first changing the structure of the glycoprotein $\mathrm{B}(\mathrm{gB})$ and glycoprotein $\mathrm{C}$ (gC) of HSV, contributing to virus glycoprotein inactivation during the viral adsorption stage [54]. Saha et al. extracted a sulfated xylogalactofucan from Laminaria angustata and found that the polysaccharide had antiviral activity by direct interaction with viral particles [55], which might mask viral structures necessary for further interactions with host cells. However, research also showed that polysaccharides from $U$. clathrata could inhibit viral fusion by preventing the intact protein F0, which was essential for the syncytia formation of Newcastle Disease Virus (NDV), from being cleaved into the mature form [56]. Compared with our results, the disparate mechanism might be due to the different extraction sources that resulted in different polysaccharides structure, and the virus was also different. To further evaluate the antiviral effect of LUPP-3, RT-PCR, western blot, and IFA were used to determine the gene and protein expression of ALV-J. Expressions of ALV-J gene and gp85 protein were observed to be significantly reduced when treated with $200 \mu \mathrm{g} / \mathrm{mL}$ and $1000 \mu \mathrm{g} / \mathrm{mL}$ LUPP-3 in RT-PCR and western-blot experiments. The results indicated that the ALV-J adsorption was suppressed and thus inhibited the subsequent life process. Results of IFA were different from that of RT-PCR and western blot, and expression of gp85 protein only reduced when handled with $1000 \mu \mathrm{g} / \mathrm{mL}$ LUPP-3. It was probably because the DF-1 cells in IFA experiment were maintained for five days after inoculation and much longer than the one day in the other two experiments. After being treated with $200 \mu \mathrm{g} / \mathrm{mL}$ LUPP-3 and inoculation, the ALV-J that 
successfully adsorb on DF-1 cells could be fully replicated, resulting in similar results compared with the viral control. However, the question of how LUPP binds to the virus surface and whether it could be specifically attached to the virus proteins which would combine with the cell receptor needs to be further illuminated in the future.

\section{Conclusion}

Initial polysaccharides from $U$. pertusa were degraded by $\mathrm{H}_{2} \mathrm{O}_{2}$ oxidative degradation. The effects of degradation conditions on the degradation process were explored; at the same time, four LUPPs were prepared. In addition, chemical composition of UPP and LUPPs was also characterized. Finally, the anti-ALV-J activity of all samples was investigated. Results showed that $\mathrm{H}_{2} \mathrm{O}_{2}$ oxidative degradation could degrade UPP effectively, and the degradation was positively related to $\mathrm{H}_{2} \mathrm{O}_{2}$ concentration and temperature and negatively to $\mathrm{pH}$. The Mw of UPP and four LUPPs was 159, 23.6, 90, 4.3, and $2.5 \mathrm{kDa}$, respectively, and the degradation did not change the chemical structure of UPP. The antiviral experiment revealed that UPP and four LUPPs could inhibit ALV-J in vitro; among them, LUPP-3 possessed the strongest anti-ALV-J effect. Subsequent study showed that LUPP-3 could bind with the viral particles and prevented ALV-J adsorption on the host cells. Further experiment indicated that LUPP-3 could reduce the infection probability of ALV-J and contributed to the significant decrease of ALV-J gene and protein expression. However, the function mechanism between LUPPs and ALVJ should be further researched. This study enhanced our understanding of LUPPs and gave guidance for its potential use in the future.

\section{Data Availability}

The authors applied for a patent for the content of this study and so it cannot be made freely available. Access to these data will be considered by the authors upon request, with the permission of Xiaolin Chen.

\section{Conflicts of Interest}

The authors declare that they have no conflicts of interest.

\section{Acknowledgments}

This work was supported by the Shandong Province Key Research and Development Project (2016YYSP010), NSFCShandong Joint Fund (U1606403), and Qingdao People's Livelihood Science and Technology Projects (16-6-2-41-nsh).

\section{Supplementary Materials}

Figure S1: chromatograms of Dextran standards with Mw of 1000. Figure S2: chromatograms of Dextran standards with Mw of 5000. Figure S3: chromatograms of Dextran standards with Mw of 12000. Figure S4: chromatograms of Dextran standards with $\mathrm{Mw}$ of 50000. Figure S5: chromatograms of Dextran standards with Mw of 80000. Figure S6: chromatograms of Dextran standards with Mw of 210000. Figure S7: HPLC profile of UPP. Figure S8: HPLC profile of LUPP-1. Figure S9: HPLC profile of LUPP-2. Figure S10: HPLC profile of LUPP-3. Figure S11: HPLC profile of LUPP4. (Supplementary Materials)

\section{References}

[1] L. Qiu, Z. Li, G. Chang et al., "Discovery of novel long noncoding RNAs induced by subgroup J avian leukosis virus infection in chicken," Developmental \& Comparative Immunology, vol. 76, pp. 292-302, 2017.

[2] L. N. Payne, S. R. Brown, N. Bumstead, K. Howes, J. A. Frazier, and M. E. Thouless, "A novel subgroup of exogenous avian leukosis virus in chickens," Journal of General Virology, vol. 72, no. 4, pp. 801-807, 1991.

[3] W. Feng, D. Zhou, W. Meng et al., "Growth retardation induced by avian leukosis virus subgroup J associated with downregulated Wnt/ $\beta$-catenin pathway," Microbial Pathogenesis, vol. 104, pp. 48-55, 2017.

[4] G. Wang, Z. Wang, P. Zhuang, X. Zhao, and Z. Cheng, "Exosomes carring gag/env of ALV-J possess negative effect on immunocytes," Microbial Pathogenesis, vol. 112, pp. 142-147, 2017.

[5] L. N. Payne and V. Nair, "The long view: 40 years of avian leukosis research," Avian Pathology, vol. 41, no. 1, pp. 11-19, 2012.

[6] Q. Xu, N. Cui, X. Ma et al., "Evaluation of a chimeric multiepitope-based DNA vaccine against subgroup J avian leukosis virus in chickens," Vaccine, vol. 34, no. 33, pp. 3751-3756, 2016.

[7] Q. Xu, X. Ma, F. Wang, H. Li, and X. Zhao, "Evaluation of a multi-epitope subunit vaccine against avian leukosis virus subgroup J in chickens," Virus Research, vol. 210, pp. 62-68, 2015.

[8] C. Liu, J. Dong, G. I. N. Waterhouse, Z. Cheng, and S. Ai, "Electrochemical immunosensor with nanocellulose-Au composite assisted multiple signal amplification for detection of avian leukosis virus subgroup J," Biosensors and Bioelectronics, vol. 101, pp. 110-115, 2018.

[9] W. Dou, H. Li, Z. Cheng et al., "Maternal antibody induced by recombinant gp85 protein vaccine adjuvanted with CpG-ODN protects against ALV-J early infection in chickens," Vaccine, vol. 31, no. 51, pp. 6144-6149, 2013.

[10] C. R. K. Glasson, I. M. Sims, S. M. Carnachan, R. de Nys, and M. Magnusson, "A cascading biorefinery process targeting sulfated polysaccharides (ulvan) from Ulva ohnoi," Algal Research, vol. 27, pp. 383-391, 2017.

[11] H. Yaich, A. B. Amira, F. Abbes et al., "Effect of extraction procedures on structural, thermal and antioxidant properties of ulvan from Ulva lactuca collected in Monastir coast," International Journal of Biological Macromolecules, vol. 105, pp. 1430-1439, 2017.

[12] C. Cai, Z. Guo, Y. Yang et al., "Inhibition of hydrogen peroxide induced injuring on human skin fibroblast by Ulva prolifera polysaccharide," International Journal of Biological Macromolecules, vol. 91, pp. 241-247, 2016.

[13] Y. Pengzhan, L. Ning, L. Xiguang, Z. Gefei, Z. Quanbin, and L. Pengcheng, "Antihyperlipidemic effects of different molecular weight sulfated polysaccharides from Ulva pertusa (Chlorophyta)," Pharmacological Research, vol. 48, no. 6, pp. 543-549, 2003. 
[14] H. Qi, Q. Zhang, T. Zhao et al., "Antioxidant activity of different sulfate content derivatives of polysaccharide extracted from Ulva pertusa (Chlorophyta) in vitro," International Journal of Biological Macromolecules, vol. 37, no. 4, pp. 195-199, 2005.

[15] T. T. T. Thanh, T. M. T. Quach, T. N. Nguyen, D. Vu Luong, M. L. Bui, and T. T. V. Tran, "Structure and cytotoxic activity of ulvan extracted from green seaweed Ulva lactuca," International Journal of Biological Macromolecules, vol. 93, pp. 695-702, 2016.

[16] D.-H. Ngo, I. Wijesekara, T.-S. Vo, Q. Van Ta, and S.-K. Kim, "Marine food-derived functional ingredients as potential antioxidants in the food industry: An overview," Food Research International, vol. 44, no. 2, pp. 523-529, 2011.

[17] I. Wijesekara, R. Pangestuti, and S.-K. Kim, "Biological activities and potential health benefits of sulfated polysaccharides derived from marine algae," Carbohydrate Polymers, vol. 84, no. 1, pp. 14-21, 2011.

[18] S. N. Fedorov, S. P. Ermakova, T. N. Zvyagintseva, and V. A. Stonik, "Anticancer and cancer preventive properties of marine polysaccharides: Some results and prospects," Marine Drugs, vol. 11, no. 12, pp. 4876-4901, 2013.

[19] H. Qi and J. Sheng, "The antihyperlipidemic mechanism of high sulfate content ulvan in rats," Marine Drugs, vol. 13, no. 6, pp. 3407-3421, 2015.

[20] M. Berri, M. Olivier, S. Holbert et al., "Ulvan from Ulva armoricana (Chlorophyta) activates the PI3K/Akt signalling pathway via TLR4 to induce intestinal cytokine production," Algal Research, vol. 28, pp. 39-47, 2017.

[21] Y.-H. Chiu, Y.-L. Chan, T.-L. Li, and C.-J. Wu, "Inhibition of Japanese Encephalitis Virus Infection by the Sulfated Polysaccharide Extracts from Ulva lactuca," Marine Biotechnology, vol. 14, no. 4, pp. 468-478, 2012.

[22] R. S. Declarador, A. E. Serrano Jr., and V. L. Corre Jr., "Ulvan extract acts as immunostimulant against white spot syndrome virus (WSSV) in juvenile black tiger shrimp Penaeus monodon," AACL Bioflux, vol. 7, no. 3, pp. 153-161, 2014.

[23] K. Hardouin, G. Bedoux, A.-S. Burlot et al., "Enzyme-assisted extraction (EAE) for the production of antiviral and antioxidant extracts from the green seaweed Ulva armoricana (Ulvales, Ulvophyceae)," Algal Research, vol. 16, pp. 233-239, 2016.

[24] Z. Zhang, X. Wang, M. Zhao, and H. Qi, "Free-radical degradation by $\mathrm{Fe} 2+/ \mathrm{Vc} / \mathrm{H} 2 \mathrm{O} 2$ and antioxidant activity of polysaccharide from Tremella fuciformis," Carbohydrate Polymers, vol. 112, pp. 578-582, 2014.

[25] Y. Diao, M. Song, Y. Zhang, L.-Y. Shi, Y. Lv, and R. Ran, "Enzymic degradation of hydroxyethyl cellulose and analysis of the substitution pattern along the polysaccharide chain," Carbohydrate Polymers, vol. 169, pp. 92-100, 2017.

[26] J. Li, B. Li, P. Geng, A.-X. Song, and J.-Y. Wu, "Ultrasonic degradation kinetics and rheological profiles of a food polysaccharide (konjac glucomannan) in water," Food Hydrocolloids, vol. 70, pp. 14-19, 2017.

[27] Y. Xu, X. Niu, N. Liu et al., "Characterization, antioxidant and hypoglycemic activities of degraded polysaccharides from blackcurrant (Ribes nigrum L.) fruits," Food Chemistry, vol. 243, pp. 26-35, 2018.

[28] P. Ramnani, R. Chitarrari, K. Tuohy et al., "Invitro fermentation and prebiotic potential of novel low molecular weight polysaccharides derived from agar and alginate seaweeds," Anaerobe, vol. 18, no. 1, pp. 1-6, 2012.

[29] T. Yamada, A. Ogamo, T. Saito, H. Uchiyama, and Y. Nakagawa, "Preparation of O-acylated low-molecular-weight carrageenans with potent anti-HIV activity and low anticoagulant effect," Carbohydrate Polymers, vol. 41, no. 2, pp. 115-120, 2000.

[30] F. Tang, F. Chen, and F. Li, "Preparation and potential in vivo anti-influenza virus activity of low molecular-weight $\kappa$ carrageenans and their derivatives," Journal of Applied Polymer Science, vol. 127, no. 3, pp. 2110-2115, 2013.

[31] W. J. Kim, J. W. Choi, W. J. Jang et al., "Low-molecular weight mannogalactofucans prevent herpes simplex virus type 1 infection via activation of Toll-like receptor 2," International Journal of Biological Macromolecules, vol. 103, pp. 286-293, 2017.

[32] Z. Zhang, X. Wang, M. Zhao, S. Yu, and H. Qi, “The immunological and antioxidant activities of polysaccharides extracted from Enteromorpha linza," International Journal of Biological Macromolecules, vol. 57, pp. 45-49, 2013.

[33] M. M. Bradford, "A rapid and sensitive method for the quantitation of microgram quantities of protein utilizing the principle of protein dye binding," Analytical Biochemistry, vol. 72, no. 1-2, pp. 248-254, 1976.

[34] M. Dubois, K. A. Gilles, J. K. Hamilton, P. A. Rebers, and F. Smith, "Colorimetric method for determination of sugars and related substances," Analytical Chemistry, vol. 28, no. 3, pp. 350356, 1956.

[35] Y. Kawai, N. Seno, and K. Anno, "A modified method for chondrosulfatase assay," Analytical Biochemistry, vol. 32, no. 2, pp. 314-321, 1969.

[36] Y. Sun, X. Chen, Z. Cheng et al., "Degradation of polysaccharides from Grateloupia filicina and their antiviral activity to avian leucosis virus subgroup J," Marine Drugs, vol. 15, no. 11, 2017.

[37] B. Li, S. Liu, R. Xing et al., "Degradation of sulfated polysaccharides from Enteromorpha prolifera and their antioxidant activities," Carbohydrate Polymers, vol. 92, no. 2, pp. 1991-1996, 2013.

[38] L. Wang, H.-M. Liu, and G.-Y. Qin, "Structure characterization and antioxidant activity of polysaccharides from Chinese quince seed meal," Food Chemistry, vol. 234, pp. 314-322, 2017.

[39] Y. Seo, H. Lee, Y. A. Kim, H. J. Youn, and B. Lee, "Effects of several salt marsh plants on mouse spleen and thymus cell proliferation using mtt assay," Ocean Science Journal, vol. 40, no. 4, pp. 209-212, 2005.

[40] L. Song, X. Chen, X. Liu et al., "Characterization and comparison of the structural features, immune-modulatory and antiavian influenza virus activities conferred by three algal sulfated polysaccharides," Marine Drugs, vol. 14, no. 1, article no. 4, 2016.

[41] H. Lü, Y. Gao, H. Shan, and Y. Lin, "Preparation and antibacterial activity studies of degraded polysaccharide selenide from Enteromorpha prolifera," Carbohydrate Polymers, vol. 107, no. 1, pp. 98-102, 2014.

[42] J.-K. Yan, Y.-Y. Wang, H.-L. Ma, and Z.-B. Wang, "Ultrasonic effects on the degradation kinetics, preliminary characterization and antioxidant activities of polysaccharides from Phellinus linteus mycelia," Ultrasonics Sonochemistry, vol. 29, pp. 251257, 2016.

[43] H. Liu, Y. Jiang, H. Yang, and B. Yang, "Structure characteristics of an acidic polysaccharide purified from banana (Musa nana Lour.) pulp and its enzymatic degradation," International Journal of Biological Macromolecules, vol. 101, pp. 299-303, 2017.

[44] Y. Hou, J. Wang, W. Jin, H. Zhang, and Q. Zhang, "Degradation of Laminaria japonica fucoidan by hydrogen peroxide and antioxidant activities of the degradation products of different molecular weights," Carbohydrate Polymers, vol. 87, no. 1, pp. 153-159, 2012. 
[45] S. H. Lee, G. Y. Jang, M. Y. Kim et al., "Physicochemical and in vitro binding properties of barley $\beta$-glucan treated with hydrogen peroxide," Food Chemistry, vol. 192, Article ID 17859, pp. 729-735, 2016.

[46] Z. Xia, S. Wu, and J. Chen, "Preparation of water soluble chitosan by hydrolysis using hydrogen peroxide," International Journal of Biological Macromolecules, vol. 59, pp. 242-245, 2013.

[47] W. Yue, P. Yao, Y. Wei, S. Li, F. Lai, and X. Liu, "An innovative method for preparation of acid-free-water-soluble lowmolecular-weight chitosan (AFWSLMWC)," Food Chemistry, vol. 108, no. 3, pp. 1082-1087, 2008.

[48] Z. Cui, S. Sun, Z. Zhang, and S. Meng, "Simultaneous endemic infections with subgroup J avian leukosis virus and reticuloendotheliosis virus in commercial and local breeds of chickens," Avian Pathology, vol. 38, no. 6, pp. 443-448, 2009.

[49] X. Wu, K. Qian, A. Qin et al., "Recombinant avian leukosis viruses of subgroup J isolated from field infected commercial layer chickens with hemangioma and myeloid leukosis possess an insertion in the e element," Veterinary Research Communications, vol. 34, no. 7, pp. 619-632, 2010.

[50] K. Qian, A.-J. Gao, M.-Y. Zhu et al., "Genistein inhibits the replication of avian leucosis virus subgroup J in DF-1 cells," Virus Research, vol. 192, pp. 114-120, 2014.

[51] J. Xie, Z. Wang, M. Shen et al., "Sulfated modification, characterization and antioxidant activities of polysaccharide from Cyclocarya paliurus," Food Hydrocolloids, 2015.

[52] J. Li, Z. Chi, L. Yu, F. Jiang, and C. Liu, "Sulfated modification, characterization, and antioxidant and moisture absorption/retention activities of a soluble neutral polysaccharide from Enteromorpha prolifera," International Journal of Biological Macromolecules, vol. 105, pp. 1544-1553, 2017.

[53] M. Yu, Y. Ji, Z. Qi et al., "Anti-tumor activity of sulfated polysaccharides from Sargassum fusiforme," Saudi Pharmaceutical Journal, vol. 25, no. 4, pp. 464-468, 2017.

[54] Q. Shi, A. Wang, Z. Lu, C. Qin, J. Hu, and J. Yin, "Overview on the antiviral activities and mechanisms of marine polysaccharides from seaweeds," Carbohydrate Research, vol. 453-454, pp. $1-9,2017$.

[55] S. Saha, M. H. Navid, S. S. Bandyopadhyay, P. Schnitzler, and B. Ray, "Sulfated polysaccharides from Laminaria angustata: Structural features and in vitro antiviral activities," Carbohydrate Polymers, vol. 87, no. 1, pp. 123-130, 2012.

[56] J. A. Aguilar-Briseño, L. E. Cruz-Suarez, J.-F. Sassi et al., "Sulphated polysaccharides from Ulva clathrata and Cladosiphon okamuranus seaweeds both inhibit viral attachment/entry and cell-cell fusion, in NDV infection," Marine Drugs, vol. 13, no. 2, pp. 697-712, 2015. 


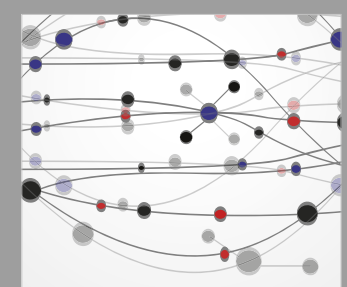

The Scientific World Journal
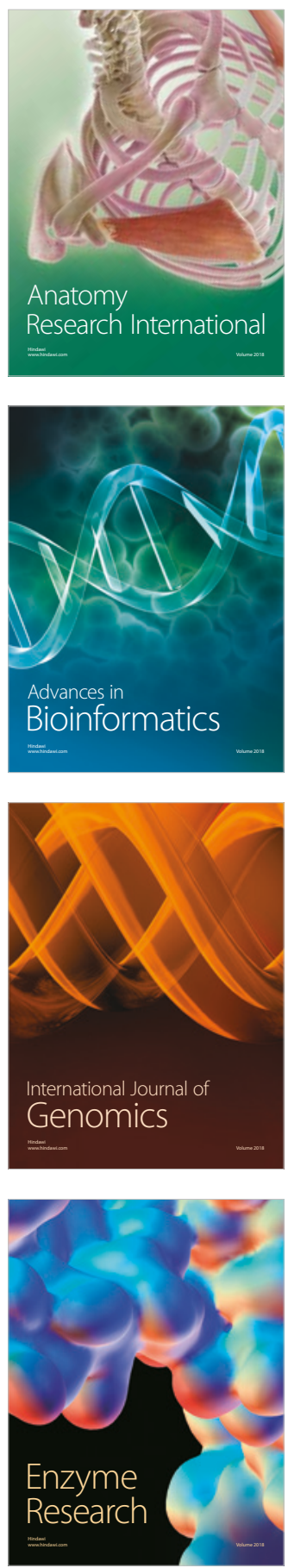
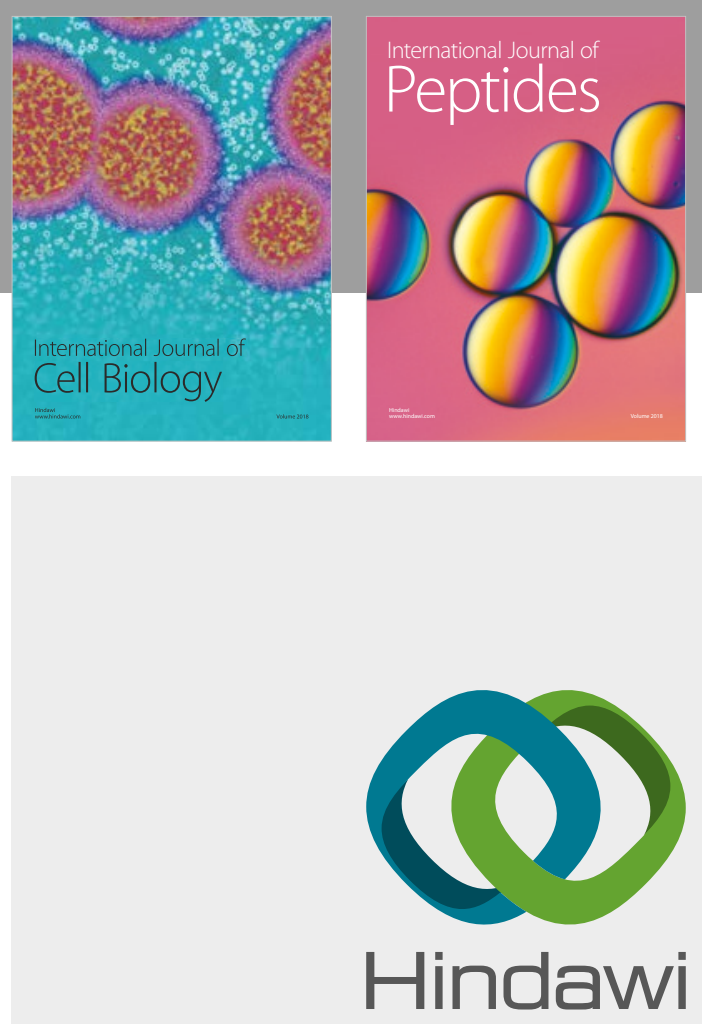

Submit your manuscripts at

www.hindawi.com
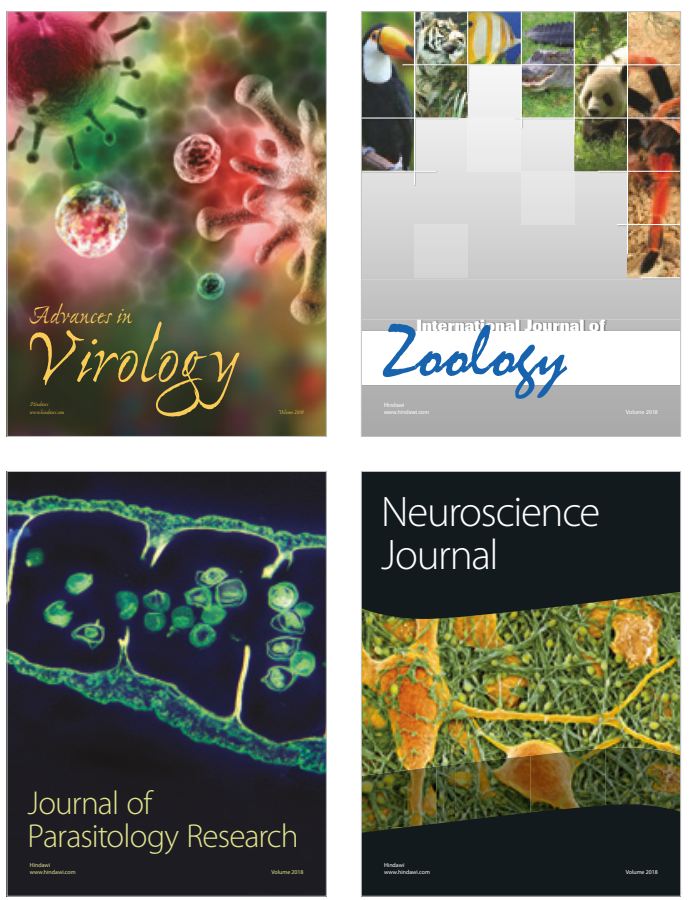
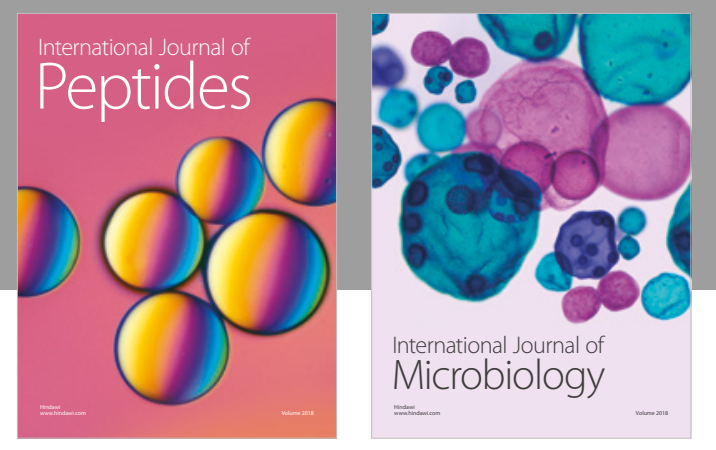

nternational Journal of Microbiology
Journal of
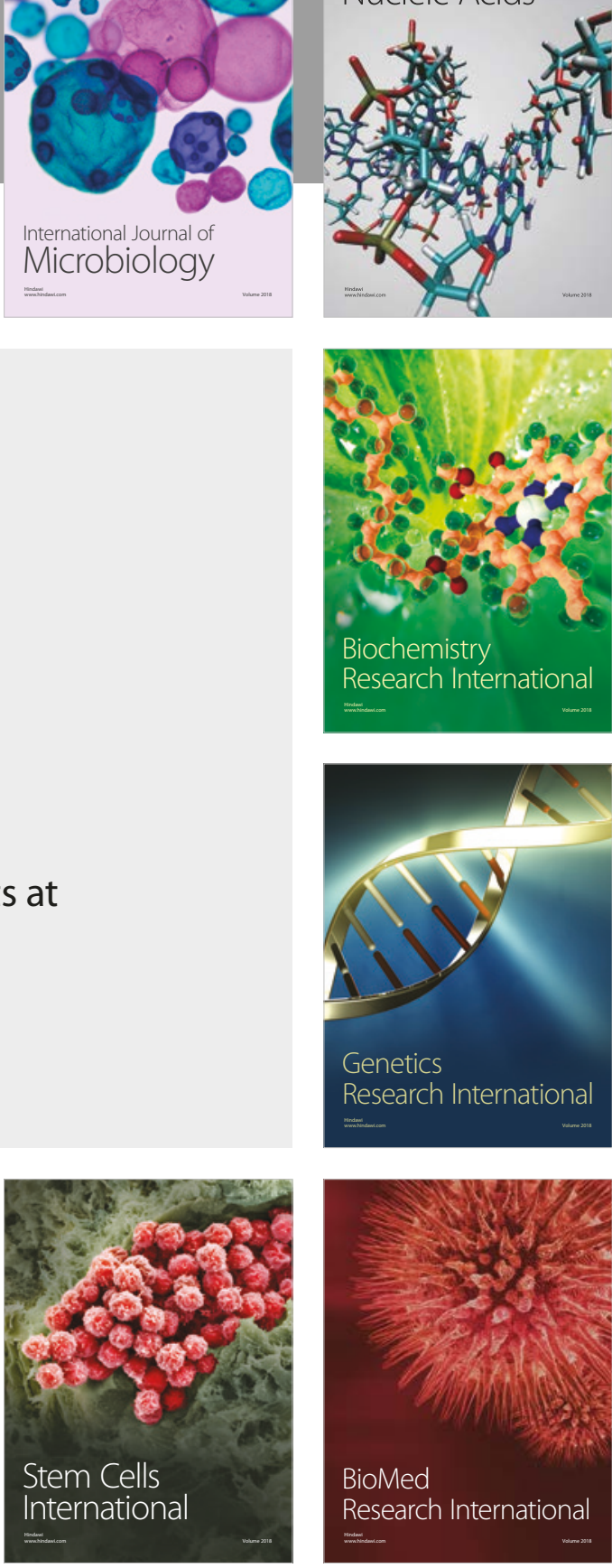
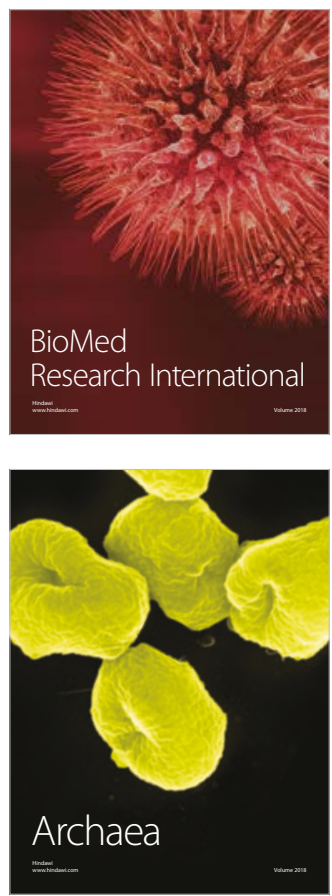